\title{
Transcendental Philosophy and the Possibility of the Given
}

\author{
Sebastian Gardner
}

In his Address to the American Philosophical Association, Dreyfus introduces his thesis concerning 'nonconceptual embodied coping' (henceforth 'NCEC') in the context of cognitive science. ${ }^{1}$ NCEC comprises the claim that 'embodied beings like us take as input energy from the physical universe and process it in such a way as to open them to a world ... without their minds needing to impose a meaning on a meaningless Given, nor their brains converting the stimulus input into reflex responses'. Dreyfus defends NCEC as an alternative to the cognitivism of Minsky et al, claiming that it receives support from the existence of the frame problem and other difficulties which cognitivism encounters in modelling the competences manifested in the performance of everyday tasks in terms of computationally realized symbolic representations. NCEC is supported independently and directly, Dreyfus argues, by Walter Freeman's work in the neurosciences, and by empirical studies and direct examination of the phenomena associated with the exercise of basic skills and the acquisition of expertise. Dreyfus describes these last considerations as 'phenomenological' and claims NCEC as a thesis found also in Merleau-Ponty and Heidegger.

This makes clear the nature of the philosophical context to which Dreyfus' claim belongs: NCEC is a thesis concerning the nature of the mental content adduced in psychological explanation, held to be supported by empirical considerations and compatible with neurological explanation, the proper measure of which in its competition with other accounts of mental content is provided by the criteria standardly employed in adjudicating a posteriori grounded theories of the mind.

In this regard, how does McDowell's thesis that conceptuality is ubiquitous in mental content (CC) compare? As Dreyfus notes, quoting from Mind and World, McDowell's 'basic point' has a different orientation: $\mathrm{CC}$ derives from consideration of what is required for the justification of perception-based belief. ${ }^{2}$ McDowell's contribution to the Inquiry debate consists in exploring ways in which CC, as a thesis formulated originally in the context of epistemology and argued in Mind and World to be required for the possibility of knowledge as such, allows itself to be extended into the sorts of domains which occupy Dreyfus, McDowell's aim being to show that the sphere defined by justification is not too narrow to encompass the data which Dreyfus cites as evidence for NCEC.

Reciprocally, Dreyfus accepts that McDowell's question of justification needs to be addressed, but he regards it as simply one consideration among others to be thrown into the mix: saying how justification is possible, according to Dreyfus, is equivalent to explaining 'how conceptual content 
arises from nonconceptual content', ${ }^{3}$ and a beginning is made on this task, Dreyfus suggests, in Samuel Todes' Body and World, while more help can be found in Being and Time. Dreyfus concedes that phenomenologists 'lack a detailed and convincing account of how rationality and language grow out of nonconceptual and nonlinguistic coping', ${ }^{4}$ but regards this as merely work for the future: he sees no difficulty in principle with the task of working out the 'step-by-step genesis of the conceptual categories that structure the space of reasons'. ${ }^{5}$

Despite their different starting points, Dreyfus and McDowell understand themselves to be arguing about the same topic, namely the extent to which content is conceptual, and accordingly regard their respective theses NCEC and CC as contradictories. Now it is no mystery that a thesis originating in epistemological reflection should come into contact with a thesis in the philosophy of mind: if solutions to epistemological problems involve claims regarding the nature of the mind and its contents, then these claims may be expected to agree with conclusions about the mind arrived at through reflection on the nature of psychological explanation, on the reasonable assumption that the mind must be one and the same thing in both contexts. From a slightly different angle, however, the configuration of the debate is puzzling. McDowell's CC is a thesis of Kantian lineage, and Kant's philosophy is transcendental, and in Kant's terms it is a mistake to allow the relevance of a posteriori theorizing about the mind to transcendental questions. Similarly, the historical figures of key importance for Dreyfus, and who are also to some extent important for McDowell - Heidegger and Merleau-Ponty belong firmly to the post-Kantian tradition and (in the relevant writings) describe their claims and concerns as transcendental. To be sure, Merleau-Ponty makes use of empirical psychology in a way that Heidegger does not, and neither is a neo-Kantian of any stripe, but it would be absurd to suggest that Phenomenology of Perception, let alone Being and Time, is simply a work in the philosophy of mind as that sub-discipline's agenda is conceived by contemporary analytic philosophers.

So the question stands: How does it come about that in the Inquiry debate certain claims which apparently belong to the context of transcendental philosophy are treated on the same level as empirically grounded theories of the minds? It may be answered that neither Dreyfus nor McDowell employs Kant's distinction of empirical and transcendental standpoints and that this is due not to any oversight but to their considered rejection of it. Be that as it may, there is all the same something to be clarified: at the very least, it would be helpful to have a clearer picture of how Dreyfus and McDowell, in view of their repudiation of Kant's separation of spheres in favour of forms of non-reductive naturalism, stand in relation to the historical figures who cast long shadows over their writings and whose philosophical authority they, to some degree, draw upon. This is particularly important, I would 
add, in light of Dreyfus' programmatic remark that the 'time is ripe to follow McDowell and others in putting aside the outmoded opposition between analytic and continental philosophy'. 6

The question of what the concept of the transcendental amounts to and its historical vicissitudes is obviously much too large for the present occasion. However, a full answer to that question it is unnecessary for my purposes, which require only that I make plausible the notion that there is a type of philosophical concern abiding from Kant to Merleau-Ponty which is staked on upholding the segregation of transcendental from empirical issues and disjoined from the project of philosophy of mind. To this end I will focus on the topic, central to Dreyfus and McDowell's concerns, of the given. What follows in Section I is a selective review of certain key moments in the treatment of the given in the history of transcendental philosophy. In Section II I will explain the bearing of my historical account on Dreyfus and McDowell.

\section{Transcendental theories of the given: a very brief history}

1. The locus classicus of transcendental philosophy's rejection of the Given is of course Kant's Transcendental Deduction of the Pure Concepts of the Understanding. This section of the Critique is extraordinarily dense and its interpretation a matter of disagreement. One well-known view, articulated famously by P. F. Strawson, maintains that a sharp line can and should be drawn between the sound epistemological argument contained (at least incipiently) in the Deduction, and the package of 'transcendental psychology' with which Kant (unfortunately) conjoins it. On Strawson's account, the latter, which involves a story of multiple faculties engaged in atemporal acts of synthesis, is tethered to Kant's incoherent metaphysics of transcendental idealism, and merely obscures the austere epistemological argument at the core of the Deduction, which after careful reconstruction will be seen to comprise a convincing refutation of Humean skepticism, fulfilling the Deduction's aim of validating empirical knowledge. ${ }^{7}$

Let it be granted for the moment that an austere analytical argument, directed at the justification of empirical belief, can be extracted from the Deduction. Does it follow that the synthesis story is otiose? In light of the Deduction's extremely high concentration of themes and multi-layered structure, and of Kant's own remarks concerning its purposes, ${ }^{8}$ it is reasonable to hypothesize that the presence of elements in the Deduction which do not contribute directly to the anti-Humean aim of empirical justification is due to its having other targets and ambitions, distinct from, albeit connected with, the aim of showing that rational grounds can be supplied for common sense beliefs about empirical reality. The notion I wish to explore is accordingly that the synthesis story is intended to explain how it is 
possible, in a specific sense which will need to be clarified, for empirical objects to be given to us, and that it is attached to a philosophical method the employment of which cannot be recast in the form of an austere Strawsonian transcendental argument. ${ }^{9}$

One sense of 'the given' is that of a purely sensory item, bare acquaintance with which suffices for non-inferentially justified judgement of the item. Call this, following Sellars and McDowell, the Given. Certainly Kant rejects this, for reasons which run in close parallel with those of McDowell. A different sense of the given, which survives rejection of the Given, is that in which it is a noncontingent part of ordinary natural consciousness that the deliverances of perceptual experience are immediately intelligible and its objects immediately, unproblematically judgeable. The existence of the given in this lower case sense is of course not merely accepted but stressed by Dreyfus and McDowell. ${ }^{10}$ The Myth of the Given can then be taken to reflect a genuine, underlying, prephilosophical datum: what makes Givenness mythic is just the supposition that this datum is adequately explained by a theory of items' presence to consciousness as due to their sheer impact on a merely receptive subject.

Having acknowledged the reality of the given, but rejected the Given, what philosophical tasks are set, or problems posed? From here we might go directly to McDowell's claim that CC captures what needs to be supposed in order for our cognitive and other rational modes of being-in-the-world to be made sense of, and to Dreyfus' counter-claim that the given demands NCEC. Instead, I want to indicate a different path, which leads us to discover a purpose for Kant's theory of synthesis. To bring this into focus, it will help to refer to Fichte.

Fichte offers the following characterization of the given, in terms which avoid the Myth: among the immediate inner and outer determinations of consciousness are, he says, some which are found to be 'accompanied by a feeling of necessity'. ${ }^{11}$ That any particular determination, or representation, is accompanied by a 'feeling of necessity' is contingent, but it is no contingency that we are in general subject to such determinations. Another name for this fact, Fichte says, is simply 'experience', Erfahrung: 'the system of experience is nothing but thinking accompanied by a feeling of necessity'. ${ }^{2}$ Fichte identifies the primary, if not total, task of philosophy with the explanation of experience: the 'object' of philosophy is the Erklärungsgrund der Erfahrung. Fichte accepts that, in advance of our actually producing an adequate explanation, it may be doubted that the question is answerable, but not that there $i s$ a question to be answered. Implied in the acceptance of Erfahrung as a transcendental explanandum, Fichte continues, is our acceptance of grounds which 'must necessarily lie outside of all experience': it 'follows from the mere thought of a basis or reason that it must lie outside of what it grounds or explains', ${ }^{13}$ hence it 'would be contradictory' to suppose that 'the explanatory ground of 
experience' belongs to experience itself or comprises a 'portion of experience'. ${ }^{14}$ The datum of givenness or fact of Erfahrung can be regarded as requiring transcendental explanation, then, only if the subject has not already been conceived as a worldly empirical item in causal communion with other empirical items - since, once that conception is accepted, the possibility of Erfahrung has been presupposed, and the only questions which then remain to be considered concern which particular empirical items induce which particular representations and by means of what mechanism they do so. Fichte identifies the pre-empirical standpoint presupposed by transcendental enquiry with pure Iconsciousness. An alternative way of formulating the relevant 'pre-mundane' standpoint, closer to Kant, is to say that philosophical reflection on the given must take as its starting point what Mark Sacks helpfully calls a 'minimally conceived domain of presentation', incorporating no more than the distinction between a content presented, and the recognition thereof. ${ }^{15}$

I want to suggest that from this starting point, paths of reflection leading to Kant's theory of synthesis may be plotted. Before describing these, it will be best to remind ourselves of two important objections to Kant's theory, advanced by F. H. Jacobi and G. E. Schulze (among others) in the early days of Kant reception and reiterated many times subsequently.

The core elements of Kant's theory are (1) the conception of synthesis as unifying activity of the subject's, and (2) the notion of bestowal of conceptual form on sensible material. To the first it is objected that, even if logical absurdity does not result from hypothesizing a non-temporal subject intentionally crafting experience behind the scenes, the hypothesis in any case contradicts the Critical aim of an immanent metaphysics of experience. The obvious objection to the second is that it too results in frustration of Kant's higher purposes, since if bestowal of conceptual form consists in its material imposition on intra-subjective sensory items, then 'empirically real' objects reduce to configurations of sense-data, and 'objectivity' to relations between them, collapsing transcendental idealism into Berkeley's empirical idealism.

Clearly, if the theory of synthesis is to amount to anything more than an outline for a possible sub-personal empirical theory of cognition, then the implications alleged must be avoided: synthesis must not be understood as an act-description referring to a mental doing on a par with say 'remembering' or 'attending', nor, more fundamentally, as any sort of operation performed on a mental object. The latter would, in fact, reduce Kant's idealism to a form of transcendental realism in which the direction of migration ${ }^{16}$ of properties has merely been reversed, yielding a story of the transposition of form from the subject's faculty of representation to its mental object; whereas what ought to be understood by transcendental idealism - if it really does, as Kant claims, break at the deepest level with all previous conceptions of cognition - is a position which allows us to avoid having to think of form as 
needing to move or be transported from one locale to another: the theory of synthesis should close the subject/object divide not by telling a story of migration, but by building the agreement of the object's form with the subject's mode of cognition into the original situation of a subject's being presented with an object.

Everything turns, accordingly, on finding a way of construing the theory of synthesis which steers clear of the imagery of a process of modification of pre-existent, materially real items. One way in which this may be done is by treating the theory as articulating essential structural features of the domain of presentation.

To conceive a domain of presentation is in the first instance to picture a space with a certain asymmetrical shape, in which a pole of necessary unity, that of the subject-presented-to, contrasts with a pole of necessary multiplicity or heterogeneity, that of the objects comprising the 'presented domain', in Sacks' terminology. Since objects presented within the domain must come together in such a way that a single unified field is constituted, the rudimentary idea of a domain of presentation incorporates not only the opposition of a One to a Many, but also a resolution of this opposition in favour of the One, a conversion or transposition of the manifold into a unity. Also involved, as a simple consequence of the domain's being so to speak looked into rather than looked at from, in McDowell's phrase, sideways on, is the fact of our own location at one end of this structure, constituting the pole of the One rather than that of the Many; with which is correlated the directionality of perspective within a domain of presentation, the fact that the object is for the subject and the subject orientated towards the object, not vice versa. Joining up these several points, we arrive at the idea that the process or function in virtue of which the manifold of a domain achieves unity consists in operations performed by the subject.

Supporting this identification is the consideration that the conditions of possibility of the given which we are attempting to lay out cannot be external to the domain of presentation itself: if the domain were insulated from the conditions which, according to our theory, make it possible, then the theory would imply that the domain of presentation is not intelligible to itself, or at least, it would fail to show that and how it is intelligible to itself; a strictly external theory would not serve the internalist end which is set when we take the domain of presentation as our starting point. The subject of presentation must stand, then, in some pre-comprehending relation to the structures described in the theory, and since this cannot of course consist in its being presented with those structures as objects, the appropriate inference is that the structures are realized for the subject in the form of operations which it performs. The subject accordingly relates to the structures as, in Henry Allison's instrumental cum teleological characterization, objectivating 'vehicles' of cognition. ${ }^{17}$ 
The introduction of activity into the theory of the given is motivated in addition by the second core element of the theory of synthesis. To the extent that the domain constitutes a field of items which the subject can potentially single out in thought, a specific mode of givenness on the part of objects is presupposed. In order for an object to figure in my domain of presentation, as opposed to merely being accessible by way of it, the object must be directly and immediately thinkable. ${ }^{18}$ The coextensiveness of what-is-presented with what-is-immediately-thinkable requires in turn that certain conditions are met.

First: If being presented with an object, and thinking that object, were opposed as instances of pure passivity and pure activity respectively, then the relation between figuring in the domain, and being thinkable, would be a contingent external relation, in need of mediation and incompatible with the object's immediate thinkability. This is avoided if the activity explicit in thought of objects is regarded as subtending the domain itself, that is, as implicated in the simple fact of an item's inclusion within it: if the domain shares its ground with whatever sponsors acts of thought, then it is intelligible that it should comprise a space across which thought can extend itself.

Second: If objects are to be immediately thinkable, then they must present themselves not as mere candidates or occasions for concept-application, but as already having some determinate character. This determining of consciousness is part of what Fichte means by a 'feeling of necessity'. In order for some object to be immediately thinkable, the application of a (basic, identifying) concept to the object must not proceed 'externally', by way of another, prior act of thought, rather the object must be presented as incorporating the conceptual character it is or can be thought to have. If we then ask how such a state of affairs is possible - How can there be an internal relation between a concept and an object-as-presented? - the answer suggests itself, again, that the object owes its conceptual subsumability to the same active operation as is responsible for its simply figuring in the domain of presentation.

These two conditions explain why the domain of presentation is not split down the middle, why it does not find itself divided between active concept-deployment and passive object-reception: if nothing separates thinking that $O$ is $F$ and thinking $O$ itself - if these can occur in the same breath then it is intelligible that empirical belief should ensue from perceptual experience in such a way that the latter is grasped as grounding the former with nothing intervening.

Finally: If subjective operations are invoked in order to account for, on the one hand, the unity of the domain of presentation, and on the other, the immediate intelligibility of presented objects, then it is a short and reasonable step to identify the two processes, i.e. to suppose that unification and conceptualization comprise one and the same operation. With which we arrive at the core of Kant's theory of synthesis. 
All too obviously, these remarks do not suffice to validate the specifics of the theory of synthesis found in Kant, nor even do they show that synthesis must employ a priori concepts. My present purpose, however, is more limited. All I wish to have made at least roughly intelligible and partly plausible is the supposition that Kant's theory of synthesis attempts to address the complex explanandum which the given presents, through a form of explanation which is concerned with neither conceptual nor causal relations, and which instead attempts to exhibit the structures which constitute the perspective of a domain of presentation. These structures are conditions of possibility and yet, since they do not bear directly on the rationality or justifiability of our beliefs, differ from the necessary conditions established by Strawsonian transcendental arguments.

The relevant distinction between these two versions or conceptions of conditions of possibility is drawn very clearly by Paul Guyer, who repudiates the non-Strawsonian sense of condition of possibility which he finds endorsed by Allison. Correctly understood, Guyer argues, Kant's arguments yield only 'an epistemological model of the confirmation of beliefs', 'the basic framework for the justification of beliefs': Kantian conditions of possibility are 'principles which would have to be appealed to in the justification of empirical claims to knowledge', 'conditions for verifying or confirming empirical judgements'. ${ }^{19}$ Allison's conception of a condition which is not psychological and yet not equivalent to a justification, Guyer considers there to be no room for.

The theory of synthesis attempts to occupy the space between psychology and justification which Guyer excludes. Whether it has a chance of success depends on its avoiding the objections cited earlier, and on there being some philosophical need to which it answers. On the first count, my earlier comments show that the theory of synthesis need not be regarded as assuming an existentially independent item as input, on which causal action is subsequently exercised, and so does not tell a story of 'imposition'. As regards the second issue, of philosophical need, consider how McDowell formulates CC: 'if an experience is world-disclosing, which implies that it is categorially unified, all its content is present in a form in which ... it is suitable to constitute contents of conceptual capacities'. ${ }^{20}$ 'All that would be needed for a bit of it to come to constitute the content of a conceptual capacity', McDowell continues, is that it 'be focused on and made to be the meaning of a linguistic expression.' While Kant might agree with McDowell that being focused on and linguistically articulated are all that 'being a content of a conceptual capacity' requires once categorially unified content has been given, the point of the theory of synthesis is to explain how any such content can be given in the first instance: the theory of synthesis is Kant's shot at locating Fichte's Erklärungsgrund der Erfahrung, and it is in those terms that it needs to be assessed. 
Whether a theory such as Kant's theory of synthesis counts as 'epistemological' depends, therefore, on how broadly we understand the project of epistemology. If epistemology is defined, following Strawson and Guyer, in terms of responding to the threat of skepticism and/or determining the rational grounds of belief and warrantedness of our knowledge claims - an exclusively 'juridical' conception of epistemology, as it may be called - then the theory of synthesis does not belong to it; but if epistemology encompasses also what might be called the metaphysics of cognition - an account of what cognition is and of its subjective grounds, in respects which go beyond their juridical properties then the theory of synthesis forms part of it. ${ }^{21}$

2. One structural feature of the minimally conceived domain of presentation is its presupposition, as we have seen, of a distinction of subject and object more fundamental than the distinction drawn by Kant between inner and outer sense - since even in the case where an object presented is inner, its distinction from the subject to whom it is presented must be articulated. Fichte's transformation of Kant's theory of synthesis into the Wissenschaftslehre's theory of object-positing may be regarded as deriving from this point. Fichte's claim is that something can be given if and only if I as it were give it to myself, i.e. posit the object in opposition to myself; only in this way, Fichte argues, can the primordial subject/object distinction be explicated. This thesis presupposes Fichte's independent account of the priority and intrinsic intelligibility of the self-relation, and it is motivated by (among other things) the inadequacy of what Fichte perceives as the only possible alternative, evidenced by K. L. Reinhold's attempt at reconstruction of Kant's account of the given, which for that reason merits brief discussion. ${ }^{22}$

One important ground of dissatisfaction with Kant's account of the given in the early reception of his philosophy focussed on Kant's attempt to establish rational communication within the given between its intellectual and sensible components. Salomon Maimon, arguing that this aim of Kant's Deduction remained unrealized and so that Hume had not been refuted, inferred from Kant's failure the need to retrieve Leibniz's conception of sensibility as defectively articulated intellection, and to reconceive cognition as involving at the final limit elimination of the given: 'what is required for completeness in the thought of an object is that nothing in it should be given and everything thought'. ${ }^{23}$

As the objections of Maimon and others accumulated, defenders of Kant's theoretical philosophy proposed ways to repair its perceived weaknesses, and on Reinhold's account, its defence demanded above all that it be equipped with an indubitable and universally accessible foundation. To this end Reinhold assigned absolute priority within the Kantian system to the concept of 'Vorstellung', by which he understood not representation in the sense of an item within a mind, but the total structure of representation inclusive of the distinction of representing subject and object represented. ${ }^{24}$ The 
reality of this structure, Reinhold argued, is assured apodictically by each and every 'fact of consciousness', since Vorstellung is simply the genus to which the various species of such facts thought, sensation, etc. - belong. By enclosing all the elements of cognition within an overarching unity, Reinhold supposed that misconceptions concerning the nature of our cognitive powers, responsible in turn for false (skeptical and dogmatic) views of the scope of our cognition, could be disposed of. ${ }^{25}$

While agreeing that Reinhold's strategy is of the kind needed, Fichte argued that Reinhold omits, crucially, the ground of the distinction of subject and object which defines the structure. ${ }^{26}$ That distinction cannot be supposed to simply 'exist' or 'occur' within the sphere of representation, in the way that a line may be drawn on a map, or a fissure appear in a natural object - it must be registered by the subject for whom it obtains, and its being registered cannot comprise a distinct state of affairs from its obtaining, since it can obtain only in so far as it is registered by the subject. One cannot, therefore, start with the sphere that Reinhold calls Vorstellung; rather, priority must be assigned to the 'I', which must be regarded as producing that sphere, i.e. as making the subject/object distinction in the dual sense of both cognizing it and making it exist. In a way that goes beyond Kant, who treats the subject as producing the unity of the object but not the articulated sphere of representation itself, Fichte proposes the 'I' as the ground which, though 'present in consciousness', ${ }^{27}$ lies 'outside of all experience' and provides its fundamental condition of possibility. Fichte, like Reinhold, can agree therefore with Maimon that the possibility of the given would be unaccountable if the heterogeneity of sensibility and understanding were allowed to remain an ultimate and irreducible condition of cognition, but since Fichte's theory of the I's object-positing promises a transcendental explanation of the existence of sensibility, Maimon's objection is overtaken. ${ }^{28}$

If the Wissenschaftslehre succeeds, then it will have been shown that Erfahrung constitutes bona fide, skeptic-proof cognition, and Maimon's neo-Leibnizian elimination of the given will be undermined. The two aims, the juridical-epistemological and the metaphysically grounding, which in Kant's Deduction allow themselves to be separated, are therefore united in the Wissenschaftslehre: while Kant's theory of synthesis pursues an aim which stands to one side of the task of refuting skepticism, Fichte's theory of object-positing is intended to achieve both the explanatory purpose of Kant's theory of synthesis and a juridical, anti-skeptical purpose.

Fichte's objection to Reinhold can be understood from an additional angle, one which is especially helpful for present purposes. Reinhold's avowed methodology, no less than Fichte's, is that of reflection on the minimal domain of presentation: the foundation of his post-Kantian Philosophy of Elements, Reinhold explains, is the power of representation as such, ${ }^{29}$ not the power of representation 
conceived as a power of the mind, and his concern is exclusively with the 'inner conditions' for representation, these being those which 'must occur within representation itself' ${ }^{30}$

Since Reinhold followed the correct method, why did he go astray? On Fichte's account, the reason is that Reinhold, driven by the thought that Critical philosophy requires an indubitable foundation, and in the grip of the assumption that indubitability is uniquely a property of facts, theorized the domain of presentation as if it could be treated as itself a fact, i.e. made an object for, or content of, itself, and thus could view itself sideways on. Reinhold attempted to construct a model which would validate itself, as required for the refutation of skepticism and by the Kantian constraint of internal intelligibility, but misconstrued this reflexivity as if it were an empirical matter, with the result that his account of the given fails to explain how the distinction essential to the existence of a domain of presentation comes to be articulated. As Schulze pointed out, Reinhold's project lead him to attempt to determine Vorstellung as a thing in itself. ${ }^{31}$ By contrast, Fichte's theory relocates the reflexivity offstage and in a non-discursive form, in the intuition of active Ichheit which can come into view only in so far as the perspective of a domain of consciousness is not merely contemplated but occupied through being enacted.

3. Just as Fichte's Wissenschaftslehre may be regarded as describing the transcendental structure which comes to light when we probe the given, so too may the opening moves of Hegel's Phenomenology of Spirit.

The Phenomenology begins with a consideration of 'the way in which' the object is 'present in' the most rudimentary objectual consciousness, wie er in ihr vorhanden ist, ${ }^{32}$ and advances by putting explicatory pressure on that notion. Consciousness in the immediacy of apprehension (Auffassen) is described as either 'reaching out' to (hinausgehen) or 'entering into' (hineingehen) the object. ${ }^{33}$ These terms recall imagery employed in the Introduction to the Phenomenology, where Hegel reported that natural consciousness conceives the relation of cognition as either a 'tool' by means of which one 'takes hold' of the object or a ray of light by means of which the object 'reaches' us, who 'receive' it. ${ }^{34}$ The target of the sense-certainty chapter is not however the common sense conception of cognition, but the attempt (associated, for Hegel, above all with Jacobi) to ground cognition on the object's sheer immediacy.

Hegel allows it to be supposed for the sake of argument that hinaus- or hineingehen are candidates for the foundation of cognition, and proceeds to show that all that can be claimed by way of constituting that which we 'reach out' or 'enter into', is 'pure' and empty being, not the being of anything in particular, not even that of the object purportedly cognized. ${ }^{35}$ The conclusion that immediate 
consciousness construed as mere hinaus-/hineingehen fails to qualify as genuine, non-empty cognition lays the ground for Hegel's positive claim, elaborated in the course of the chapter, that genuine, i.e. determinate, cognition requires begreifen, conceptual grasping.

To the extent that our interest lies in the justification of knowledge claims, the lesson of Hegel's critique of sense-certainty is therefore simply that cognition demands conceptualization. But while Hegel does of course wish to reaffirm this Kantian thesis, his ultimate interest in exhibiting the 'poverty' or 'emptiness' of cognition reduced below the level of conceptual grasping lies again - like Kant's theory of synthesis and Fichte's theory of object-positing - with the pre-juridical conditions of possibility of givenness, the more fundamental order which precedes and underpins the relation of justification constitutive of ordinary empirical consciousness. What will transpire eventually - after consciousness through multiple twists and turns has achieved 'the representation of reason', the certainty that consciousness 'is all reality' ${ }^{36}$ - that the given must be conceived as embedded within a heavily modified, concept-based version of Fichte's subject-object identity, and the sense-certainty chapter aims to provide the first step in Hegel's argument to that conclusion.

This becomes clear when we note Hegel's innovation to transcendental theory of the given and the departure that he thereby makes from Kant and Fichte.

Mid-way through the dialectic of sense-certainty, a point is reached where putatively immediate consciousness - which is endeavouring to hold fast to what it 'means', i.e. its intended object, in the face of the challenge posed by reflection, which asks which particular object is intended; and which has also learned that neither consciousness itself, nor the object on its own, can do the work needed redefines itself 'as a whole which stands firm within itself as immediacy and by so doing excludes from itself all the opposition which previously took place'. ${ }^{37}$ This 'pure immediacy' or 'pure intuiting' is sealed within itself: Hegel says that it refuses to 'come forth' when other objects are drawn to its attention and that it allows 'no distinction whatever' to 'penetrate' it. ${ }^{38}$

In the next moment of the dialectic - in which we endeavour to explicate vicariously this mute, autistic consciousness which has turned its back on the demands of reflection - we 'approach it' and 'point to' its object on its behalf. ${ }^{39}$ Here then two standpoints which were previously identified - that of the (natural) consciousness under observation, and that of the (philosophical) consciousness which observes it - have been separated out.

The next twist of the dialectic alerts us to the puzzle which we now confront.

The phenomenological observer realizes that, in order for him to point to the correct object the one that immediate consciousness has in mind - he needs to 'enter into', to allow himself to be 'made into', the very same singular point of immediate consciousness as he is observing. ${ }^{40}$ The result of 
such an identification, however, would be to merely repeat the experience of stultification, since the phenomenological observer would then share immediate consciousness' inability to articulate itself.

We appear, therefore, to have arrived at an impasse: we began with the apparently unproblematic idea, enshrined in Kant's concept of intuition, of a subject directly presented with an object in its particularity, but reflection on this idea has revealed a contradiction: on the one hand, the standpoint of phenomenological observation must collapse itself into that of the immediate consciousness under observation, in order to understand what it 'means', i.e. identify the object it intends, while on the other hand this same end requires that it hold itself apart, i.e. locate itself outside and oppose itself to the consciousness observed.

What this aporia compels us to recognize, Hegel supposes, is that when we (phenomenological observers) conceive consciousness as related immediately to a particular object, we must be bringing to bear some structure, some richer set of materials, than is disclosed from within the perspective of immediate consciousness, and since this structure is not an inner aspect of the object's givenness, Hegel supposes that it cannot be intuitional. The remainder of the sense-certainty chapter begins to lay out this non-intuitional, hence conceptual structure: Hegel argues that 'this', 'here', 'now', and other indexicals must be understood as 'universals', and concludes his analysis with the claim that sensecertainty 'is nothing but' the 'history' of its 'movement', ${ }^{41}$ a structure which incorporates negativity and the holistic interrelation of its elements - this 'Here' is not that 'Here', yet belongs to a 'simple ensemble of many Heres', etc. ${ }^{42}$

With this talk of sense-certainty as a conceptual 'movement', Hegel's thesis of the autonomy of conceptuality has begun to show itself, and since his doctrine of the Concept of course opposes Kant and Fichte, it is important to grasp exactly how the discussion of sense-certainty has invited it in.

As already indicated, Kant and (more explicitly) Fichte conceive transcendental theory in perspectival terms; repeatedly, Fichte explains that the philosopher in constructing the Wissenschaftslehre is merely re-enacting, and constructing a model of, the 'acts of mind' of the $I c h{ }^{43}$ Now Hegel agrees that transcendental theory must be taken to represent what is internal to subjectivity - else it fails to model a genuine cognitive achievement of the subject's - but the fact that the structure must be realized in the perspective of the subject does not entail that it arises from it, and Hegel's claim is that there is no pressure for us to think so. In the Phenomenology Hegel employs the duplex structure of observed and observing consciousnesses in such a way as to create space for his thesis of the autonomy of the conceptual, in a way that contrasts with Fichte's account of the method of the Wissenschaftslehre: on Hegel's account, when we observers recognize that, in order for the aporia in 
our construal of sense-certainty to be resolved, a conceptual structure must be brought into play, then that structure should be understood as self-subsistent and directly authoritative.

Hegel's absolute idealist metaphysics of reason and subject-object identity occupies therefore, in terms of its bearing on the question of the possibility of the given, the same role as Kant's theory of synthesis and Fichte's theory of object-positing. The crucial difference is that, if Hegel is right, then the theory need not and should not be regarded as specifically anchored in, restricted to, or validated by the perspective of the subject, since it merely spells out what is already in play, implicitly, when 'the perspective of the subject' is made the object of philosophical scrutiny. This means that - though there is of course much further to go, because many other contexts need to be worked through - Hegel has in the sense-certainty chapter, if his argument works, broken the back of subjectivism: philosophical reflection is to be conceived henceforth not as attempting to show us how we can, from the inside, 'get outside' of ourselves - a conception of the philosophical task to which Kant and Fichte continue to subscribe - but as retrieving and making explicit structures which must be regarded as immanent within the perspective of the subject and yet do not owe their validity to the subject's, nor to any other, mere 'perspective'.

Hegel's point may be put in focus by returning once again to Reinhold. Vorstellung is treated by Reinhold as revealing necessarily in our acquaintance with it an intrinsic transparency and unconditional intelligibility. The unravelling of this assumption provokes Fichte, we saw, to embed Vorstellung within the encompassing orbit of the absolute Ich. The different and more radical conclusion which Hegel extracts involves a reflexive realization on the part of philosophical consciousness: it is not merely that there must be more to the domain of presentation than Reinhold supposes, rather the philosophical conception of the domain of presentation as primitive, as entitled to methodological primacy, is itself a version of the Myth of the Given, or in Hegel's language, 'immediacy'; from which it follows that Fichte's proposal, whatever its improvement over Reinhold, is ultimately equally ill-conceived.

Hegel's relation to the transcendental standpoint of the domain of presentation is thus doubleedged. Hegel does not foreswear the Kantian-Fichtean transcendental starting-point: reflection on the given initiates the argument of the Phenomenology, and gives us our first, vital lesson in the method employed in that work and the metaphysics which accompany it. But the moral of that reflection is an anti-subjectivism.

4. Supposing the nature of transcendental treatments of the given, as found in Kant and German Idealism, to have been made at least roughly clear, to what extent is that model followed also by the 
existential phenomenologists? Again the topic is huge, so I will need to be extremely brief. What I hope to make plausible is that, despite massive departures from 'classical' transcendentalism, existential phenomenology retains distinctive transcendental traits.

In his seminal commentary on Being and Time, Dreyfus claims that Heidegger's understanding of fundamental ontology can be glossed adequately in terms of 'intelligibility' and our 'making sense of things'. ${ }^{44}$ The claim is contentious but vital for Dreyfus' purposes, since it allows him to treat Heidegger's account of Dasein as self-standing and as at least pointing in the direction of the concerns of philosophy of mind: ${ }^{45}$ for if to ask about the meaning of Being just is to ask how we make sense of the world, then 'fundamental ontology' and 'analysis of Dasein' are effectively interchangeable. ${ }^{46}$ If, however, an independent and prior grasp of the Seinsfrage is necessary in order to grasp the specific problem which the analysis of Dasein is intended to address, and if furthermore the Seinsfrage conditions the very sense of that analysis and its results, then the question must be raised whether NCEC, as Dreyfus formulates it, can be a thesis of Heidegger's at all.

In the Letter on Humanism Heidegger comments on a locution that he employs on one occasion in Being and Time: 'Es gibt Sein. ${ }^{47}$ Heidegger explains that 'es gibt' is used in Being and Time 'purposely' and should be understood literally as 'it gives' (for which reason the French il y a does not provide an accurate translation): 'For the "it" which here "gives" is Being itself.' Why speak in this manner? Heidegger explains that he writes 'es gibt Sein' in order to avoid 'Being is', because the verb 'is' is appropriate to entities but not to Being itself - to use 'is' of Being would be to misrepresent Being as an entity. 'Es gibt Sein', by contrast, renders the 'primal mystery' of Parmenides' 'For there is being' the word 'gibt' designates the essence of being as 'granting its truth'. In a still later text, On Time and Being, Heidegger revisits the notion that 'es gibt Sein', now saying that the task is to bring into view the 'It' and its 'giving', das Es und sein Geben in die Sicht zu bringen. ${ }^{48}$ This task, he says, breaks with Western metaphysics, which thinks Being but not the 'Es gibt' 'as such'. ${ }^{49}$

The issue surrounding 'Es gibt Sein' derives, as phenomenological method demands, from consideration of the given. One dimension of the given which neither Fichte nor Hegel put in explicit focus - whether or not it creates a problem for their accounts, as Schelling alleges, and as Jacobi claims that it does for any form of idealism - consists in the existential awareness which the given necessarily incorporates. Heidegger, in this respect as in many others standing close to Schelling, maintains that the existential component of the given cannot be regarded as merely supervening on the object's being posited (Fichte), nor as merely the first term of conceptual mediation (Hegel). ${ }^{50}$ The Being of beings, Heidegger supposes, must be a further fact, distinct from the fact that beings are intelligible and make sense to us, and from the (equivalent) fact that beings are encountered with determinate features; 
otherwise there would be nothing for 'Es gibt Sein' to register. The question of the ground of the existential component of the given - in Heidegger's preferred terms, the question concerning the nature of the 'It' which 'gives' - comprises an explanandum of the same manifestly transcendental rank as those addressed by Kant, Fichte and Hegel. Heidegger's analytic of Dasein - the account of Care, equipmentality and so on, within which everything that Heidegger has to say about practical activity is nested - should thus be regarded as an attempt to illuminate this fact, i.e. to address the question of how Being can 'give', or of how anything can be given as being. And if we look back to Heidegger's texts of 1927, we find it explained quite clearly that the constitution of Dasein is formulated as a theme for philosophical enquiry only in so far as Dasein is regarded as relaying the meaning of Being via its 'understanding of being', i.e. in so far as Dasein is that to which Being is given, the site where the 'Es gibt' of Being comes to light (its 'Lichtung'). ${ }^{51}$ Equally clear, from for example Heidegger's repudiation of 'anthropology, psychology, and biology' in $\llbracket 10$ of Being and Time, is the internal connection of the analytic of Dasein with the Seinsfrage. ${ }^{52}$

In all of this, skilled coping behaviour as a psychological explanandum is nowhere in sight: embodied coping is of interest to Heidegger, not under that ('ontic') description as such, but in so far as - by way of Interpretation - it belongs to a transcendental explanans. ${ }^{53} \mathrm{NCEC}$, in the form Dreyfus gives it, could not play that explanatory role. This is not yet enough to show that NCEC cannot be a thesis of Heidegger's at some very subordinate level, but pending an account of how NCEC can be connected logically with a transcendentally orientated theory of Dasein, the claim should be regarded with skepticism.

If this is correct, then Dreyfus, by isolating and foregrounding the theme of skilled coping behaviour in Being and Time, may be considered to have interpolated a set of concerns which (at the very least) do not lie at the core of Heidegger's philosophy, and which are properly regarded - to the extent that our business with Heidegger is not a matter of radical reconstructive surgery - as inseparable from transcendental concerns, from which they lie firmly downstream.

Parallel remarks apply to Dreyfus' recruitment of Merleau-Ponty. While NCEC is a thesis concerning the nature of the mental content to be adduced in the explanation of skilled behaviours, at the end of the day Merleau-Ponty, as I read him, is not in this line of business at all: part of the point of Phenomenology of Perception is I think to persuade us to withdraw human subjectivity at large altogether from psychological-explanatory contexts. ${ }^{54}$ As I read him, Merleau-Ponty's strategy of playing off empiricist and intellectualist explanations against one another is designed, not to create space for a third type of explanation competing on the same level, but to show us the need to extract perception altogether from that context and to relate it instead to the transcendental, non-empirical fact 
of there being given to us a differentiated object-world, which comprises the real explanandum of the Phenomenology. The metaphilosophical design of the Phenomenology - to demonstrate the necessity of our shifting up from a psychological-explanatory to a pre-objective transcendental appreciation of perception, by showing that empiricism and intellectualism jointly lead objective thought into antinomies - is not acknowledged by Dreyfus. Dreyfus believes that he follows Merleau-Ponty in seeking to steer perception out of objective thought, but this requires Dreyfus' deflationary interpretation of pre-objectivity, which becomes on his account indistinguishable from the sorts of subpersonal inputs theorized by empirical psychologists; Dreyfus reduces pre-objectivity to a property of information states - their merely being incompletely processed ${ }^{55}$ - whereas Merleau-Ponty regards pre-objectivity as correlatively and equally an attribute of the world, carrying anti-realist, metaphysical implications.

Later I will say more in support of my claim that Dreyfus has cut himself loose from the historical Merleau-Ponty, and reconstructed in his place a figure whose concerns fit onto the agenda of contemporary analytic philosophy of mind. For now it should just be noted how Dreyfus reduces the 'job of phenomenologists' to the business of merely 'get[ting] clear concerning the phenomena that need to be explained'. ${ }^{56}$ Since Dreyfus retains from phenomenology none of the elements which are required in order for it to offer anything that might count as philosophical explanation - Husserl's thesis of the absoluteness of transcendental consciousness, Heidegger's conception of Dasein as the site of Sein's self-unconcealing, Merleau-Ponty's idealism of pre-objective being: all these Dreyfus sacrifices through either explicit rejection or deflationary interpretation of the relevant concepts - nothing remains for phenomenology except a task of close observation and cataloguing of data due to receive their explanation elsewhere. ${ }^{57}$ It is consequently puzzling when Dreyfus announces that phenomenologists 'owe us an account' of how the conceptual emerges from the nonconceptual, ${ }^{58}$ since his conception of phenomenology makes it hard to understand how it could give an account which is not merely descriptive but genuinely explanatory of anything as philosophically large-scale as conceptuality. ${ }^{59}$

\section{Dreyfus, McDowell, and transcendentalism}

1. My historical survey has touched on a number of issues. It will help to review these, and to say something about what circumscribes transcendental philosophy, before returning to Dreyfus and McDowell. 
I have argued that three distinguishable philosophical projects may be engaged in reflection on the given: (i) epistemology in the narrow 'juridical' sense defined earlier; (ii) philosophy of mind, which takes the mind as an empirical content of empirical reality or nature; and (iii) transcendental enquiry, which seeks to determine the pre-empirical explanatory grounds of the empirical sphere. ${ }^{60}$ Though combinable in various ways, it is important to be clear about which of these project(s) is (are) being pursued in any given case.

Paramount for transcendental philosophy is the denial that a theory of mental content can take the place or do the work of a transcendental explanation: from the transcendental standpoint, the attempt to grasp in the form of an empirical configuration the structure which defines the domain within which empirical forms can appear repeats Reinhold's mistake of suppressing perspectivality. Transcendentalism as such does not, however, impose a veto on philosophical consideration of the mind as an empirical object: it implies only that the project of philosophy of mind occupies a secondary place in the full philosophical picture, simply in the sense that transcendental concerns are more fundamental. The two philosophical projects come into conflict only if either (1) the transcendentalist denies, in addition, that there is any cogent sense in which the mind can be ascribed empirical reality (the position of Heidegger and Sartre, for example, but not of Kant or Hegel); or (2) the working assumption of the philosophy of mind that the mind is to be considered an empirical object is raised up and asserted as a final metaphysical fact, one which there is no need, and which it makes no sense, for us to attempt to get behind or ground transcendentally. The latter is a claim that many philosophers of mind will of course wish to make, but it is not a presupposition of the philosophical analysis of mind as an empirical object.

The relation of transcendental philosophy to epistemology is more complex, since justificatory concerns - though weakened by the time of existential phenomenology - are of course what originally, in Kant, motivates the transcendental turn, and they remain central in German Idealism. Again, the important point for present purposes is that transcendental treatment of epistemological themes extends beyond what is required in order to settle juridical issues. Thus in the case of the given, the full transcendental aim includes determining the conditions which make it possible for something to be given in advance of and in abstraction from the given's justificatory role. Accordingly, transcendental enquiry goes beyond claims to the effect merely that the empirical sphere necessarily has a certain form, ${ }^{61}$ and transcendental arguments of the austere Strawsonian type do not exhaust its ambitions.

Transcendental enquiry may affirm, but is not committed to, the existence of a non-empirical or metaphysical subject numerically distinct from the empirical subject, nor to idealism of the strength found in Kant. What it does maintain is that empirical subjectivity requires explication, in the sense that 
insight must be achieved into how the subject, from a pre-empirical basis, comes to grasp itself as a content of empirical reality, to the extent that it does so. The refusal to take the subject's empirical reality for granted $a b$ initio is complemented by a commitment to idealism only in the weak sense that representation of the world is held to stand in necessary interconnection with pre-empirical features of the subject.

That the primary object of transcendental enquiry is not the mind, as contemporary philosophy of mind understands it, raises the question: If not about the mind, what then, if anything, are transcendental claims 'about', and what makes them true? Without pretending that talk of articulating the structure of the domain of presentation does anything very much to answer this 64 million dollar question, the appropriate thing to do in the present context, in which the aim is only to circumscribe transcendentalism as a certain broad type of philosophical endeavour, is just to point out that the metaphilosophical question of the status and truth-conditions of transcendental claims has been central to the internal business of transcendentalism: following a line of descent from Reinhold's abstraction of Vorstellung from the mind as such, and Fichte's theory of a genetic deduction of ordinary consciousness, down to Heidegger's theory of formal indication and Merleau-Ponty's deictic conception of phenomenological truth, the issue of how transcendental claims should be theorized - whether as 'purely formal', 'virtual', 'regulative', 'postulative', 'metaphysical', 'transcendental-psychological', 'ontological', or whatever - has been high on the transcendentalist agenda.

2. How does Dreyfus stand in relation to transcendentalism? This is fairly clear-cut, for there is I think little to distinguish Dreyfus metaphilosophically in transcendentalist eyes from mainstream analytic naturalism, and that when Dreyfus declares that the wall is finally down, the prospect of union with analytic philosophy on the terms envisaged by Dreyfus is one that transcendentalist continental philosopher should balk at.

This is perhaps clearest when Dreyfus gives his view the nonconceptual ground level which, he believes, lies beyond the reach of McDowell's conceptualist imperialism. ${ }^{62}$ In the course of their debate, McDowell reveals the plasticity of his notion of conceptuality, obliging Dreyfus to dig ever deeper in order to locate a stratum on which conceptuality cannot plausibly be supposed to encroach. This, however, threatens to recast the whole debate in terms of the older argument in the philosophy of mind between those (like McDowell and Jennifer Hornsby) who affirm and those (like Daniel Dennett) who deny the autonomy and explanatory self-sufficiency of personal, as opposed to sub-personal, explanation. The debate between Dreyfus and McDowell is however surely intended by both parties to bear on what lies at the personal level: Dreyfus wishes to argue, not for nonconceptual subpersonality, 
but for nonconceptuality as a dimension of personal-level being (Dreyfus' alignment with Heidegger depends on this). Now Dreyfus asserts not merely that we discover as a matter of (phenomenological) fact a dependence of conceptuality on nonconceptuality; he also offers - in his critique of what he calls 'representationalism' ${ }^{63}$ - arguments which parallel closely the sub-personalist's standard strategy of arguing that there simply must be some machinery ticking over below the personal level on the grounds that propositional attitudes and other such folksy mental entities are insufficiently robust to stand on their own two feet. The question thus arises of what distinguishes Dreyfus' ground floor from subpersonal territory, and I suggest that when Dreyfus takes as his paradigm of nonconceptuality something as relatively microscopic as my hand's adjusting itself to the shape of the doorknob, ${ }^{64}$ the personal-level status of his nonconceptualism is not secure. The doubt is reinforced when we are told that 'subjectivity', 'reference to a subject', awareness of oneself 'even in some minimal way', are altogether stripped out of nonconceptuality, ${ }^{65}$ from which the very distinction of subject and object is missing. ${ }^{66}$ If however Dreyfus' counter to McDowell does resolve itself into the claim that the execution of personal-level actions involves certain unconceptualized sub-personal occurrences, then (presumably) this is a point that McDowell can accept, for it was never part of the brief of conceptualism to maintain the conceptuality of elements which are sub-personal components of the execution of coping, but not themselves instances of coping. ${ }^{67}$

Dreyfus' specific claim that his thesis of nonconceptualism is found in the existential phenomenologists assumes that they share his conception of what it is to be either 'conceptual' or 'nonconceptual', as if these were universal terms of art. But it needs to be asked if one and the same idea is in play in the discourses of phenomenology or classical German philosophy and contemporary philosophy of psychology. The conceptual/nonconceptual distinction is after all not part of the equipment of common sense psychology: we introduce it in order to do specific theoretical work, and what makes the property of 'being conceptualized' or 'involving concepts' definite is a surrounding philosophical apparatus. Thus for example Kant's thesis of the dependence of objective experience on $a$ priori conceptuality is well-defined, and it makes sense to ask, as commentators do, whether Kant upholds certain specific sub-theses concerning (for example) the dependence of the synthesis of the imagination on that of the understanding, whether intuition independently of the understanding has objectual reference, and so on. The same applies, in their own terms, to Fichte's and Hegel's accounts of the involvement of concepts in the given. Present-day philosophy of mind however is not concerned with issues as formulated in classical German philosophy, and it cannot be simply taken for granted that historical figures have anything to say about the conceptualism vs. nonconceptualism debate in the philosophy of mind, since the terms in which it is cast are foreign to transcendental philosophy's 
starting and end points. ${ }^{68}$ When the contexts of philosophical theses - the sorts of reasons given in their support, the problems which they are intended to resolve, the constraints to which they are subject, the implications which they are held to carry - diverge so widely, the notion that an identical philosophical thesis ('all content is conceptualized') can travel across contexts begins to disintegrate.

To illustrate and support the point just made: Dreyfus is most confident that Merleau-Ponty fits the bill of a nonconceptualist (Heidegger, Dreyfus acknowledges, seems partly or at times of McDowell's view ${ }^{69}$ ). To be sure, Merleau-Ponty thinks that intentionality extends down very far indeed from self-conscious self-determining subjectivity, and he can afford to do so without for a moment worrying that he has tipped over the edge and abandoned intentionality for mere mechanical nature, because he considers that human subjectivity is ontologically continuous with a pre-objective reality which (his Phenomenology indicates and later writings make clear) has all of the strangeness of a naturphilosophisch absolute-idealist reprise of Leibniz's metaphysics of active force. But does the fact that Merleau-Ponty upholds the merely negative claim that the specific kind of conceptuality which marks out what he calls objective thought fails to percolate all the way down, mean that he thereby holds the same view as certain contemporary cognitive scientists occupied with sub-personal information-processing? To suppose so is again to take a very relaxed view of the criteria of sameness for philosophical theses.

Examination of the Phenomenology shows that Merleau-Ponty's thesis of pre-objectivity is in any case not in fact squarely opposed, in the manner of Dreyfus' NCEC, to Kant's claim concerning the necessity of understanding or McDowell's CC. At some points Merleau-Ponty may appear to draw a straight contrast of understanding with perception, but also and equally he talks of a 'reform' of the understanding: the rediscovery of pre-objectivity means, Merleau-Ponty says, that the understanding (l'entendement) 'needs to be redefined, since the general connective function ultimately attributed to it by Kantianism is now spread over the whole intentional life and no longer suffices to distinguish it'. ${ }^{70}$ The opposition of 'perceptual life' and 'concept' can gain application, Merleau-Ponty says, only when analytical reflection has falsely dissected the intentional tissue of sense experience into two reified classes, a collection of sensory atoms and a set of connecting principles. ${ }^{71}$ Other passages reiterate and amplify the thought that the task is reconceive the necessary relation of perceptual and motor contents with the understanding or 'symbolic function'. ${ }^{72}$

Now if pre-objectivity involves the understanding, as Merleau-Ponty redefines it, then this shows one of two things. If we suppose that l'entendement entails conceptuality, then we must say that on Merleau-Ponty's account conceptuality is present in pre-objectivity, and so that it must be uncoupled from objective thought, which should be defined in terms of a specific form of conceptual 
representation, one generated by analytical reflection. ${ }^{73}$ Alternatively, we may conclude that MerleauPonty's thesis of pre-objectivity is not concerned at all with the empirical property of being conceptualized in Dreyfus' sense of the material or functional constitutional infiltration of experiential content by concepts; from which it would follow that NCEC - since it sits within a realist framework and involves no recognition of pre-objectivity in Merleau-Ponty's metaphysical sense - is not an alternative to objective thought but a form of (in Merleau-Ponty's sense) empiricism. Either way, the line that Dreyfus draws between 'conceptual' and 'nonconceptual' does not align with Merleau-Ponty's central distinction.

3. McDowell's relation to the historical legacy of transcendentalism is at once much closer and much harder to pin down.

On the one hand, McDowell's prioritization of the issue of justification and explicit engagement with the central transcendental explanandum concerning the possibility of a concept's having an object or a belief's having objective purport, ${ }^{74}$ along with his (apparent) ascription of a transcendental role to 'second nature' as a Hegelian successor to Kantian synthesis and Fichtean positing, and his inclusion of nature within the space of reasons, may all seem to show him pursuing straightforwardly transcendental aims. ${ }^{75}$ Yet also central to McDowell's project are the quietist, diagnostic-therapeutic, exorcistic elements from Wittgenstein, which appear to give compelling reason for regarding McDowell as, to the contrary, declining the transcendental project: McDowell maintains that '[m]oves in the language of traditional philosophy can be aimed at having the right not to worry about its problems, rather than at solving those problems', ${ }^{76}$ and describes Mind and World as aiming to give explanations which unmask as illusion our seeming 'to be confronted with philosophical obligations of a familiar sort'. ${ }^{77}$ Such remarks imply that what may appear to be transcendentalist theses in McDowell should be read (at the end of the day) not as answers to, but as refusals of, transcendental questions. If accordingly McDowell's engagement with transcendentalism is quasi-deconstructive, a provisional adoption of transcendentalist ways of thinking for the purpose of demonstrating how they, by their own lights, yield to an enriched conception of nature, then the kind of meaning possessed by McDowell's seemingly transcendental assertions will depend on which sector - whether pre- or post-exorcism - of philosophical thought we occupy. ${ }^{78}$

It is worth noting one fundamental respect in which McDowell's transcendentalism must in any case be regarded as scaled down. In my account of the transcendental project, I emphasized its pursuit, over the horizon of justification, of pre-empirical grounds. McDowell's inclusion of nature within the space of reasons may seem to satisfy this description. McDowell himself does not however regard that 
claim as entailing any sort of metaphysical commitment, and this seems plausible, in so far as the conception of a reason operative in McDowell - the notion of what a reason as such $i s$ - is restricted to that of something we can give, employ or use to a normative end, something the being of which is exhausted in the justificatory role it can play for us. ${ }^{79}$ Thus McDowell cites Sellars' identification of the space of reasons as the space 'of justifying and being able to justify what one says'. ${ }^{80}$ Reflection on what goes on within the space of reasons so defined does not, however, equip us with an account of the space of reasons itself. In Kant's terms, McDowell's juridically defined space of reasons is merely the space of the understanding, which needs to be located in turn within the space of (theoretical and pure practical) reason, and in Hegel's too, it remains that of the mere Verstand, not that of Vernunft - it spans the rational relations involved in our cognizing determinate objects, but does not articulate the ground of those relations. ${ }^{81}$ The shortfall, measured by traditional transcendental lights, consists in McDowell's silence regarding the nature and status of the space in which we do our reason-giving, and the metaphysical issue of how the space of reasons is grounded - how it either gets to be launched, or supplies its own ground. To draw an analogy with Kant's treatment of space in the Transcendental Aesthetic, it is as if McDowell stops with the proofs of space's a priori necessity and declines to take up the further question of space's transcendental reality or ideality.

The next question is whether this truncation of the transcendental project supplies the basis for a criticism of McDowell. In place of the detailed discussion which would be required in order to return an answer to this question, I wish just to describe a general respect in which McDowell's position may be considered open to transcendentalist criticism. The key question is whether McDowell is entitled to turn his spade or shrug his shoulders at points where the transcendentalist rolls up his sleeves. ${ }^{82}$ McDowell embraces the overarching transcendental explanandum, since he affirms that the possibility in general of a relationship between thought and object - 'objective purport' - is something that demands explanation. The question, accordingly, is why McDowell interprets the task which is thereby set in relatively constricted terms: If the possibility of objective purport deserves explanation, then why does this not involve positive substantial accounts of (i) the conceptualizedness which makes possible the immediate thinkability of given objects, (ii) the bare possibility (questioned by Maimon) of an intelligible relation between the sensible and the conceptual, (iii) the a priori necessary properties of Bildung in virtue of which it can lead us into a space of reasons with a sound title to objectivity, (iv) the properties of first nature in virtue of which it invites our empirical cognition, (v) the unity-anddifferentiation of first and second nature, and so forth $?^{83}$

McDowell has replied to critics on these sorts of points, and since there is no space here to discuss his responses, let me just assume that the issues are not settled, and move on to the following 
point: The classical transcendentalist will insist that in order to rationalize his position, McDowell needs at the very least to explain the general, principled basis on which the reach of transcendental explanation is, on his account, properly determined. The suspicion must be allayed that what determines McDowell's restricted interpretation of the transcendental task is his prior and independent commitment to the avoidance of what he calls (rampant) platonism: for if a prior substantial commitment to naturalism is what in fact dictates the degree of McDowell's involvement with transcendental questions, then the transcendentalist will reasonably object that things have been got back to front, and that the projected exorcism relies on an insufficiently whole-hearted appreciation of our transcendental-philosophical obligations. McDowell will then have failed to unsettle the transcendentalist's belief in the necessity of pursuing the transcendental task, once taken up, all the way to its bitter platonic end.

4. The puzzle with which I began consisted in the fact that, in the Inquiry debate, the distinction between transcendental and a posteriori claims appears to have been erased, contrary to what the avowed historical allegiances of Dreyfus and McDowell lead one to expect. If my characterization of transcendental philosophy is on the right track, then Dreyfus and McDowell should be credited with very different orientations with respect to the post-Kantian legacy: Dreyfus in effect abjures the transcendental project in order to undertake the task - wholly legitimate in its own terms, once freed from accompanying historical claims - of recasting themes in phenomenology for broadly naturalistic purposes, while McDowell proposes a quasi-deconstructive reformation of the transcendental tradition. The disagreement of Dreyfus and McDowell reflects this divergence: McDowell's transcendental orientation, qualified as it may be, leads him to prioritize normative considerations and thence to CC, while Dreyfus' post-transcendental outlook makes room for his nonconceptualism.

While this historical contextualization sheds some light on Dreyfus and McDowell's disagreement, it does not directly help to resolve it, and it may even seem to imply that the argument cannot be resolved at the non-metaphilosophical level at which it is pursued in the Inquiry exchange. This is a plausible conclusion, in so far as the sorts of alleged counter-instances to CC adduced by Dreyfus tend (I argued) to sub-personality, while McDowell's prioritization of normativity - which to Dreyfus appears arbitrary - in any case makes it hard to see how any accumulation of putatively nonconceptual phenomenological or other a posteriori data could, by McDowell's lights, undermine CC. ${ }^{84}$ That said, I want to indicate a respect in which there is I think scope for an effective criticism to be made of McDowell's conceptualism from Dreyfus' standpoint, on the condition that an important modification is made to the latter. 
Given that for McDowell as much as for Dreyfus, what we arrive at ultimately, once our transcendental anxieties have been dispelled and the standpoint of pre-mundane subjectivity which motivates skeptical reflection has been closed down, is an understanding of ourselves as natural entities in a (ontologically rich) natural world, it is unclear why it should be necessary to arrive at this allimportant truth via a specifically transcendental route. This is not to say that the route to that truth should involve instead, as Dreyfus proposes, an account of how conceptuality and rationality 'arise from' or 'grow out of' nonconceptuality; Dreyfus' commitment to telling a story of the 'genesis' of conceptuality, it seems to me, is a burden that does not assist the case for NCEC. But there is another way in which we can think of ourselves as coming into possession of the all-important truth that Dreyfus and McDowell agree on, which involves nothing more abstruse than direct confrontation with the manifest fact of our being-in-the-world, appreciation of which (to the extent that it is needed) is assisted by immersing ourselves in the sort of Heideggerian picture which Dreyfus teases out of Division I of Being and Time. ${ }^{85}$

McDowell may object that this is too blunt, too external, too sideways-on, to give satisfaction, and that it therefore makes no contribution to the problem at hand. But in making any such reply - and indeed simply by dint of having adhered to the traditional transcendental path - McDowell exposes himself to the objection that he reveals himself to lie still under the influence of the assumption of firstperson privilege and the correlative necessity of domain-of-presentation theorizing. In other words, Dreyfus may object that it is only when one's basic conception of the nature of justification is unduly conditioned by transcendentalism that one will see fit to abstract 'experience' from the world and to reify it as a 'tribunal', yielding the subject-object problematic with which Mind and World begins. The fantasy of extra-mundane existence which this conception incorporates, Dreyfus may assert, is better confronted and extirpated at root than indulged. Proceeding in this way, Dreyfus can point out, avoids being saddled with McDowell's thesis of the inclusion of the world within the space of reasons - a thesis which, however often McDowell may remind us that it is 'only a reminder', does not seem to shed its spookiness. ${ }^{86}$

And with transcendental worries laid to rest, there is scope for instating nonconceptuality. If there are no longer any transcendental roles to be played, then there is no longer anything to be feared from NCEC: nonconceptual content, just as it cannot be invoked to help explain conceptuality, cannot threaten to interpose an epistemic barrier between mind and world or otherwise reactivate transcendental anxieties; it can have no transcendental bearing, either negative or positive. With the transcendental pressure off, the existence or not of nonconceptual content can be allowed to become a purely phenomenological or otherwise a posteriori matter. 
In sum, Dreyfus may argue that McDowell's conception of exorcism as operating from the inside of the illusion targeted is bound to leave it at least half alive - in so far as, for example, the image of nature as lying within the conceptual realm seems forever on the verge of a Fichtean or Hegelian reinflation - and so has less to recommend it as a therapeutic measure than the alternative, which involves nothing more than insistently ostending the fact of our being 'always already' in the world.

What allows the criticism of McDowell just outlined to be made, it should be noted, is the fact that McDowell distinguishes between the two aims of (a) providing therapy for our anxieties, and (b) exhibiting transcendentally the rationality of the mind-world relation, and that he subordinates the latter to an overarching therapeutic context, to that extent denying the autonomy of transcendental concerns. The denial is essential if McDowell is to represent the transcendental ladder as something to be kicked aside once it has been climbed, i.e. if we are to avoid thinking of transcendental assertions as instances of 'constructive philosophy'. ${ }^{87}$ It is however just this degree of standing back from the transcendental agenda, this refusal to grant the sheer rational inexorability of transcendental problems $a b$ initio, which makes room for the objection that McDowell's chosen method of internal exorcism to achieve his therapeutic aim is (at best) under-motivated. That the therapeutic, post-transcendental aspect of McDowell's position should create a vulnerability will be regarded by the classical transcendentalist as evidence of the rub between the two aspects of McDowell's project.

It goes without saying that from this nothing follows regarding the vindication of classical transcendentalism. Indeed, to the extent that McDowell's assumption that we must at all costs avoid 'rampant' platonism remains unchallenged, no such result is in the offing. My intention here has just been to indicate how McDowell may be thought to be squeezed from two sides, and so to emphasize the fineness of the line that McDowell's ingenious departure from transcendental orthodoxy requires him to tread.

I have sought to cast doubt on the assumption that transcendental conclusions about 'the mind' are in principle intertranslatable with conclusions arrived at in the philosophy of mind. The mind should not be regarded as a given, ready-made philosophical topic, on which we can alight without having already made broad metaphysical decisions which crucially pre-determine the kinds of results that enquiry can arrive at. The coming into coincidence of post-analytic and post-Kantian continental philosophy is not exactly a myth, but it ought, I think, to be viewed as problematic, and not yet realized in a complete and systematic form. McDowell comes as close as anyone to an integration of the two traditions, but I have argued that considerably more is at stake in this than, as McDowell sometimes puts it, 'domesticating' 
the rhetoric of post-Kantianism. Fostering the interaction of analytic and continental philosophy does not after all, we should remind ourselves, require us to make their unification a regulative ideal.

\section{References}

Allison, Henry (1983), Kant's Transcendental Idealism: An Interpretation and Defense (New Haven: Yale University Press).

Bell, David (2001), 'Is Empirical Realism Compatible with Transcendental Idealism?', in Ralph

Schumacher ed., Idealismus als Theorie der Repräsentation? (Paderborn: Mentis).

Cassam, Quassim (2007), The Possibility of Knowledge (Oxford: Oxford University Press).

Dreyfus, Hubert (1990), Being-in-the-World: A Commentary on Heidegger's Being and Time, Division I (Cambridge, Mass.: MIT Press).

Dreyfus, Hubert (2005), 'Overcoming the Myth of the Mental: How Philosophers Can Profit from the Phenomenology of Everyday Expertise', Proceedings and Addresses of the American Philosophical Association 79, 47-65.

Dreyfus, Hubert (2007a), 'The Return of the Myth of the Mental', Inquiry 50, 352-365.

Dreyfus, Hubert (2007b), 'Response to McDowell', Inquiry 50, 371-377.

Fichte, J. G. (1797), '[First] Introduction to the Wissenschaftslehre', in Introductions to the Wissenschaftslehre and Other Writings (1797-1800), trans. and ed. Daniel Breazeale (Indianapolis: Hackett, 1994), pp. 2-35.

Fichte. J. G. (1801), A Crystal Clear Report to the General Public Concerning the Actual Essence of the Newest Philosophy: An Attempt to Force the Reader to Understand, trans. John Botterman and William Rasch, in Philosophy of German Idealism: Fichte, Jacobi, and Schelling, ed. Ernst Behler (New York: Continuum, 1987).

Fichte, J. G. (1988), Early Philosophical Writings, trans. and ed. Daniel Breazeale (Ithaca, N.Y.: Cornell University Press).

Gardner, Sebastian (forthcoming), 'Merleau-Ponty's Transcendental Theory of Perception', in The Transcendental Turn, ed. Mark Sacks, Sebastian Gardner and Matthew Grist.

Guyer, Paul (1987), Kant and the Claims of Knowledge (Cambridge: Cambridge University Press). Halbig, Christoph (2008), 'Varieties of Nature in Hegel and McDowell', in Lindgaard 2008.

Hegel, G. W. F. (1807), Phenomenology of Spirit, trans. A. V. Miller, Oxford: Oxford University Press, 1977. 
Heidegger, Martin (1927a), Being and Time, trans. John Macquarrie and Edward Robinson (Oxford: Basil Blackwell, 1978).

Heidegger, Martin (1927b), The Basic Problems of Phenomenology, trans. and ed. Albert Hofstadter (Bloomington: Indiana University Press, 1982).

Heidegger, Martin (1947), 'Letter on Humanism', trans. Frank Capuzzi, in Pathmarks, ed. William McNeill (Cambridge: Cambridge University Press, 1998).

Heidegger, Martin (1962), On Time and Being, trans. Joan Stambaugh (Chicago: University of Chicago Press, 2002).

Hudin, Jennifer (2006), 'Motor Intentionality and its Primordiality', Inquiry 19, 573-590.

Jensen, Rasmus Thybo (2009), 'Motor Intentionality and the Case of Schneider', Phenomenology and the Cognitive Sciences 8, 371-88.

Kant, Immanuel (1781/1787), Critique of Pure Reason, trans. (Cambridge: Cambridge University Press, 1998).

Kant, Immanuel (1783), Prolegomena to any Future Metaphysics, trans. and ed. L. W. Beck (Indianapolis: Bobbs-Merrill, 1980).

Larmore, Charles (2002), 'Attending to Reasons', in Nicholas H. Smith ed., Reading McDowell: On Mind and World (London: Routledge).

Lindgaard, Jakob, ed. (2008), John McDowell: Experience, Norm, and Nature (Oxford: Blackwell). MacDonald, Cynthia, and Graham MacDonald, eds. (2006), McDowell and His Critics (Oxford: Blackwell).

McDowell, John (1994), Mind and World (Cambridge, Mass.: Harvard University Press).

McDowell, John (1995), 'Knowledge and the Internal', Philosophy and Phenomenological Research 55, 877-893.

McDowell, John (1996), Introduction to Mind and World, 2nd edn. (Cambridge, Mass.: Harvard University Press).

McDowell, John (1998), 'Having the World in View: Sellars, Kant, and Intentionality', Journal of Philosophy, 95, 431-492.

McDowell, John (2007a), 'What Myth?', Inquiry 50, 338-351.

McDowell, John (2007b), 'Response to Dreyfus', Inquiry 50, 366-370.

McDowell, John (2008a), 'Avoiding the Myth of the Given', in Lindgaard 2008.

McDowell, John (2008b), 'Responses', in Lindgaard 2008.

McManus, Denis (2008), 'Rules, Regression and the "Background": Dreyfus, Heidegger and McDowell', European Journal of Philosophy 16, 432-458. 
Maimon, Salomon (1790), Essay on Transcendental Philosophy, trans. Alistair Welchman et al. (London: Continuum, 2010).

Merleau-Ponty, Maurice (1945), Phenomenology of Perception, trans. Colin Smith (London: Routledge \& Kegan Paul, 1962).

Merleau-Ponty, Maurice (1946), 'The Primacy of Perception and its Philosophical Consequences', trans. James M. Edie, in The Primacy of Perception: And Other Essays on Phenomenological Psychology, the Philosophy of Art, History and Politics (Evanston, Ill.: Northwestern University Press, 1964).

Reinhold, K. L. (1796), Versuch einer neuen Theorie des Vorstellungsvermögens, 2nd edn. (Prag u. Jena: Widtmann u. Mauke).

Rödl, Sebastian (2007), 'Eliminating Externality', Internationales Jahrbuch des Deutschen Idealismus 5, 176-188.

Rorty, Richard (1998), 'The Very Idea of Human Answerability to the World: John McDowell's Version of Empiricism', in Truth and Progress: Philosophical Papers, Vol. 3 (Cambridge: Cambridge University Press).

Sacks, Mark (2000), Objectivity and Insight (Oxford: Oxford University Press).

Sacks, Mark (2005), 'The Nature of Transcendental Arguments', International Journal of Philosophical Studies 13, 439-460.

Scheler, Max (1966 [5th edn., revised]), Formalism in Ethics and Non-Formal Ethics of Values: A New Attempt toward the Foundation of an Ethical Personalism (Evanston: Northwestern University Press, 1973).

Schulze, Gottlob Ernst (1792), Aenesidemus oder über die Fundamente der von dem Herrn Prof. Reinhold in Jena gelieferten Elementar-Philosophie ([Helmstädt]).

Sellars, Wilfrid (1963), 'Empiricism and the Philosophy of Mind', in Science, Perception and Reality (London: Routledge \& Kegan Paul).

Stern, Robert (1999), 'Going Beyond the Kantian Philosophy: On McDowell's Hegelian Critique of Kant', European Journal of Philosophy 7, 247-274. 


\section{Notes}

${ }^{1}$ Dreyfus 2005, pp. 48-55.

${ }^{2}$ Dreyfus 2005, p. 58.

${ }^{3}$ Dreyfus 2005, p. 59.

${ }^{4}$ Dreyfus 2005, p. 61; reiterated in 2007a, p. 364.

${ }^{5}$ Dreyfus 2005, p. 61.

${ }^{6}$ Dreyfus 2005, p. 61.

${ }^{7}$ That the synthesis story should be dispensed with is a conclusion reached also by Mark Sacks, from an angle more internal to Kant. Sacks argues that a reconstruction of the Deduction which presupposes synthesis but not atomism yields only conclusions too weak for Kant's purposes (Sacks 2000, pp. 71-5, 98-111), while a reconstruction which presupposes perceptual atomism in addition, though it delivers the desired conclusions, is flawed by its presupposition of a specific model of the mind, a doctrine which is contestable and frustrates the deeper insight in transcendental idealism (pp. 76-87, 111-129, 268-272, 312). Scheler's objections to Kantian synthesis overlap with Sacks': see Scheler 1966, pp. 6567.

${ }^{8}$ Kant 1781/1787, A xvi-xvii.

${ }^{9}$ In this connection, see Sacks 2005.

${ }^{10}$ See McDowell 2008a, p. 1, referring to Sellars 1963, p. 127.

${ }^{11}$ Fichte 1797, §1, 422-424; pp. 7-9.

${ }^{12}$ Fichte 1797, $\$ 4,428$, p. 13.

${ }^{13}$ Fichte 1797, §2, 424-425; p. 9

${ }^{14}$ Fichte 1797, §4, 428; p. 14.

${ }^{15}$ See Sacks 2000, pp. 228-235.

${ }^{16}$ wandern: Kant 1783, §9, 4:282.

${ }^{17}$ See Allison 1983, pp. 10, 83-85, 165.

${ }^{18}$ The opening paragraph of the Transcendental Aesthetic (A19/B33) may be read as asserting the necessity of the immediately thinkability of objects given to us. Kant distinguishes (i) the necessity, for all and any cognition, of Anschauung, the element in cognition by means of which it relates immediately to objects, from (ii) the specific necessity, for cognition in subjects of our sort, that the intuited object be given. Kant furthermore identifies cognition's immediate relatedness to the object with thought's achieving the 'end' towards which it is 'directed as a means', worauf alles Denken als 
Mittel abzweckt. It is thus implied that, when an object is given to us, thought finds itself in direct possession of the object. Kant is thus rejecting as inconceivable a scenario in which a thinker lacks anything which it can recognize as its experiencing or intuiting of objects. Interestingly, Merleau-Ponty suggests that such alienation from objects is exactly the condition of the thinking subject implied by 'intellectualists', but if so, it is an implication that Kant sought to avoid (as Merleau-Ponty partly recognizes).

${ }^{19}$ See Guyer 1987, pp. 258-259 and 303-305; Guyer refers to Allison's explicit denial (1983, p. 297) that Kant is concerned with 'conditions of the justification or verification of particular knowledge claims'. Despite some appearance to the contrary, arising from his avowed focus on the 'means' of knowledge and disengagement from skeptical challenges, the conception of conditions of possibility in Cassam 2007 is restricted similarly to juridical grounds of belief or knowledge: Cassam takes the scope of an account of 'how knowledge is possible' to be set by the removal of 'obstacles', and these are identified in terms of threats to relations of justification.

${ }^{20}$ McDowell 2007a, pp. 347-348.

${ }^{21}$ A distinction between narrower and broader senses of epistemology is drawn by McDowell 1998, pp. 435-437, and Kant is aligned with the latter, but McDowell's broader sense remains narrower than that just defined.

${ }^{22}$ What follows relates to the Elementarphilosophie in its earlier, historically influential version of 1789-1790.

${ }^{23}$ Maimon 1790, 57, p. 240. In order for there to be real cognition, it must be the case that 'the understanding does not subject something given a posteriori to its a priori rules; rather it lets it arise [läßt entstehen] in accordance with these rules (which I believe is the only way to answer the question quid juris? in a wholly satisfactory way)' (81-83, p. 48).

24 See Reinhold 1796, Buch II.

${ }^{25}$ See e.g. Reinhold 1796, pp. 181-184.

${ }^{26}$ See Fichte's 'Review of Aenesidemus' (1794), in Fichte 1988, pp. 62-65, and Fichte's letter to Reinhold, July 2, 1795, in Fichte 1988, pp. 399-400: to say that the elements of the manifold 'are given' means that 'you do not know' how they are arrived at (p. 400). I single out one of Fichte's criticisms of Reinhold among several.

${ }^{27}$ First Introduction, §4, 428, p. 14.

${ }^{28}$ See Outline of the Distinctive Character of the Wissenschaftslehre with Respect to the Theoretical Faculty, Sect. V, in Fichte 1988: 'Sensation must be posited' (p. 260). 
${ }^{29}$ Reinhold 1796, p. 205.

${ }^{30}$ Reinhold 1796, p. 196, 199-200.

${ }^{31}$ Schulze 1792. Sacks 2000, p. 235 n 27, states the requirement on transcendental theory that the structure of experience not be determined as transcendentally real.

${ }^{32}$ Hegel 1807, $\$ 94$.

${ }^{33}$ Hegel 1807, $\S 91$.

${ }^{34}$ Hegel 1807, §73.

${ }^{35}$ Hegel 1807, §99.

${ }^{36}$ Hegel 1807, §230.

${ }^{37}$ Hegel 1807, §103.

${ }^{38}$ Hegel 1807, §104-105.

${ }^{39}$ Hegel 1807, §105.

${ }^{40}$ Hegel 1807, §105.

${ }^{41}$ Hegel 1807, §109.

${ }^{42}$ Hegel 1807, $\$ 110$.

${ }^{43}$ See especially Fichte 1801.

${ }^{44}$ See, e.g., Dreyfus 1991, p. 3.

${ }^{45}$ See Dreyfus 1991, chs. 1-2.

${ }^{46}$ This alone is not enough to show NCEC to belong to Heidegger's analysis of Dasein, but it is a necessary step in Dreyfus' argument.

${ }^{47}$ Heidegger 1927a, II43(c), p. 255; Heidegger 1947, pp. 254-255.

${ }^{48}$ Heidegger 1962, p. 5. In this work, Heidegger denies that 'Being' adequately identifies the 'It', and the place of Being is taken by 'Ereignis'.

${ }^{49}$ Heidegger 1962, p. 8.

${ }^{50}$ Heidegger's thesis is reaffirmed, and made much of, by Sartre.

${ }^{51}$ See Heidegger 1927a, II[ 4 4-5, pp. 32-40, and 1927b, pp. 227-229. The existential analytic of Dasein proceeds 'with explicit orientation towards the problem of Being', whence it receives its 'existential justification' (1927a, p. 37).

${ }^{52}$ The most that I can see, which might seem to favour the opposite view, is Heidegger's admission that there is continuity of analysis of Dasein with philosophische Anthropologie, in 1927a, I28, pp. 169170. 
${ }^{53}$ The notion of transcendental explanation - and perhaps of any form of philosophical explanation - is sacrificed in the later Heidegger, but in Being and Time it retains its purchase.

${ }^{54}$ Argued in Gardner (forthcoming). See, e.g., Merleau-Ponty 1945, p. 63: 'psychological considerations' are merely what leads us from the natural attitude to 'the transcendental problem'. Note also the numerous places in which Merleau-Ponty opposes 'third person' misconceptions: pp. 55, 75, 79 n2, 80, 120, 123, 174-175, 198, and his reservations concerning 'explanation', e.g. pp. xx, 433.

${ }^{55}$ See Dreyfus 2007a, p. 359, concentrating on the theme of the 'indeterminacy' of content.

${ }^{56}$ Dreyfus 2005, p. 50; and see p. 53.

${ }^{57}$ See Dreyfus 2005, pp. 49-50 and p. 53.

${ }^{58}$ Dreyfus 2007a, p. 364.

${ }^{59}$ The value of phenomenology is a central topic in Dreyfus' exchange with John Searle. On the presently relevant point - philosophical explanatoriness - I do not see that Dreyfus answers Searle.

${ }^{60}$ For a succinct characterization of transcendental explanation, see Bell 2001, sect. 2.

${ }^{61}$ Scheler makes clear the distinction of 'the facts of the a priori', from 'attempts to make the a priori understandable or even to explain it' (1966, p. 65).

${ }^{62}$ Dreyfus 2007a and 2007b.

${ }^{63}$ See the analysis of Dreyfus' arguments in McManus 2008.

${ }^{64}$ Dreyfus 2007a, pp. 361-362, 2007b, pp. 374-5. Hudin brings out the sub-personality of Dreyfus' conception, 2006, 578-582.

${ }^{65}$ Dreyfus 2007b, pp. 373-374. Dreyfus' appeal to Sartre in this context goes awry, since even in The Transcendence of the Ego pre-reflective object-consciousness is a non-positional consciousness of itself, 'conscience (de) soi', a self-synthesizing unity which is for itself a subject opposed to an object. ${ }^{66}$ Dreyfus 1990, p. 5: 'being-in-the-world ... cannot be understood in subject/object terms'.

${ }^{67}$ See McDowell 2008a, pp. 12-13.

${ }^{68}$ Thus Kant treats the topic of empirical psychology under the heading of anthropology, a 'pragmatic' discipline.

${ }^{69}$ Dreyfus 2007b, p. 377 n4.

${ }^{70}$ Merleau-Ponty 1945, pp. 49, 53; see also, e.g., p. 144, the comments on rationality on pp. xix-xx and p. 430, and Merleau-Ponty's 'new definition of the a priori' (p. 220).

${ }^{71}$ Merleau-Ponty 1945, p. 53. 
${ }^{72}$ See esp. Merleau-Ponty 1945, pp. 126-127, which talks of the need to conceive a 'dialectic of form and content' in which neither is reduced to the other. To which corresponds Merleau-Ponty's new conception of the relation of the a priori and a posteriori, pp. 220-222.

73 This is exactly how Merleau-Ponty explains his position in 1946, pp. 18-19: 'One of Kant's discoveries, whose consequences we have not yet fully grasped, is that all our experience of the world is throughout a tissue of concepts which lead to irreducible contradictions if we attempt to take them in an absolute sense or transfer them into pure being, and that they nevertheless found the structure of all our phenomena, of everything which is for us' (italics added); Kant's limitation is that his 'philosophy itself failed to utilize this principle fully'. See also Merleau-Ponty 1945, pp. 218-222, on intellectualist $v s$. phenomenological conceptions of reflection.

${ }^{74}$ In McDowell 1994, pp. 41-44 and 95-104, 'the transcendental framework' is associated with Kant's erroneous positing of things in themselves outside the space of reasons, but in later writings (1998, p. 445, and 2008b, pp. 209-210) 'transcendental' is what concerns 'the objective purport of our conceptual activity' or (equivalently, for McDowell) what is needed to 'vindicate the legitimacy' of objective experience.

75 And, correlatively, taking metaphysical worries at face value: see McDowell's 'Response to Bilgrami' in MacDonald and MacDonald eds. 2006, pp. 66-68.

${ }^{76}$ McDowell 1994, p. 155 n30.

${ }^{77}$ McDowell 1996, p. xi; see also pp. xx-xxi.

${ }^{78}$ Note the echo here of Hegel's 'overcoming' of the domain of presentation by means of immanent critique, described earlier; McDowell departs from Hegel in denying that we are thereby carried forward to a new, contentful philosophical thesis.

79 This follows from his rejection of '(rampant) platonism': see McDowell 1994, p. 77.

${ }^{80}$ Sellars 1963, p. 169; McDowell 1996, p. xiv, and 2008a, p. 1.

${ }^{81}$ On how Hegel's agenda and ambitions exceed McDowell's, see Stern 1999, pp. 259-264, and Halbig 2008.

82 See e.g. McDowell 1994, p. 178.

${ }^{83}$ On these various points see, e.g., Halbig 2008, Larmore 2002, Rödl 2007, and Sacks 2000, pp. 166168.

${ }^{84}$ The dialectic accordingly goes as follows. For McDowell it is axiomatic that our first move in considering world-directed states and episodes should be to put them 'in a normative context' (McDowell 1996, pp. xi-xii). Dreyfus protests that on the evidence 'perception has a function more 
basic than justification' (Dreyfus 2005, p. 16). But the function cited by Dreyfus, viz. of 'opening onto a world', is one that McDowell's conceptualism can assimilate, on the basis that all modes of openness to the world involve rationality (McDowell 2007a, pp. 343-344). See also Jensen's conclusion, 2009, p. 387.

${ }^{85}$ Note that such an approach may declare itself innocent of the 'interiorization of the space of reasons' which according to McDowell (1995) underpins much epistemology, and equally remote from the annihilation of the space of reasons entailed, in McDowell's view, by 'full-blown externalism'. ${ }^{86}$ These comments echo some of what is said in Rorty (1998).

${ }^{87}$ As McDowell points out (2008b, p. 225), the ladder is not kicked aside as nonsensical; but if anything distinguishes philosophical therapy from philosophical problem-solving, it must nonetheless undergo some sort of semantic deflation. 